\title{
Finding the Image of God: Searching the 'Sublime' through works of Rene Descartes and H.P Lovecraft
}

\section{Sayan Chattopadhyay}

\begin{abstract}
This study explores the "Sublime" and aims at clarifying the very 'understood' as well as 'misunderstood' figure or image of God(s) and showing how the established and vivid definitions of the Almighty can be discarded with the help of certain 'Infinist' concepts and the 'De-Humanization' of God. It also aims at presenting a new perspective towards the understanding of the 'humanization' that happened and shows the loop-holes in its definition i.e. given to date all around the world. This paper focuses upon searching the acceptability and validity of Rene Descartes' Ontological Argument, through which I examine the image of God as I find the image of God being repeated and, therefore, I would also raise the understandings from the Ontological Argument which is later debated through the concept of "theodicy" by Leibniz and which is altered and given an altered definition by H.P Lovecraft in the era of modernization. There has been a repeatation in the understanding of God and it's Image. Infinism supports my statement, as it speaks of this Literature loop which is present and misunderstood very commonly as something new. A comparative methodology has been used in order to study the various theories upon God or Sublime from different ages, in order to study the changing images of God and the reasons behind it. The article presents my unique understanding of God that is different from the romantic understanding and the concept propogated in Monotheism.
\end{abstract}

\section{Keywords}

De-humanization. Infinism, Sublime, Ontological argument, Theodicy, Cosmic Horror, God 



\title{
Finding the Image of God: Searching the Sublime through works of Rene Descartes and H.P Lovecraft
}

\author{
Sayan Chattopadhyay
}

The concept of "Sublime" is often discussed in world literature, mostly as the figure of "God". Multiple explanations and understandings over multiple periods of times, give us the very understanding of Who this God is. The omniscient, omnipresent, and omnipotent figure, being one of the most common subject in texts is also highly misunderstood and misinterpreted. God has been fabricated into Literature so deeply that we get the Almighty's name in nearly every genre of literature, that be Romantic, Metaphysical, Horror, War, fiction, weird literature. This study explores my conceptions over the topic based on 'European' and 'American literature'. It presents an analtsis of the theories concreting/ discarding the existence of God, and searching for theories, that claims to elaborate upon the image that a God has. My project hence focuses upon that 'not so discussed' section which speaks of something beyond what we may consider as God. Is God good, Bad, or how is he and what is his image that we have at present times, are some of the questions that I've tried to discuss here in my paper. I have also worked over the understandings of Infinism as it supports my understanding of the loop in literature which is unnoticed by nearly everybody deconstructing a text.

Religions and politics are also important in the understanding of God or the Sublime figure we are trying to comprehend and make a part of our society. Whenever, this interpretation is forwarded, it gives a new meaning towards Hope, Life and Deeds. In this article the aim is to clarify the 'understood' as well as 'misunderstood' figure or image of God(s) and showing how the very established and vivid definitions of the Almighty can be discarded with the help of certain 'Infinist' concepts and the very 'DeHumanization' of God. It also aims to present a new perspective towards the understanding of the 'humanization' that happened and shows the very loop-holes in it's definition i.e. given till date all around the world. This project is also the very first project to include the understandings of 'Infinism' in order to analyze the identity of The One and to simplify it's significance.

\section{Critical Discussion}

In academics or in Christianity, I have seen that the conception of God that is 
taught or made understood to us is largely having a form, one which is humanized or like a human. The humanized God has a form, more likely to that of a human being and having features and qualities of a Human as well. It can be found well in nearly any Asian or European mythology we have been growing into listening stories of and also in paintings after the age of European renaissance where Gods were drawn in the image of humans. For example : the figure of Krishna in Mahabharata from Hindu mythology, the character of Jesus from Christianity, or even the character of Odin from Norse mythology. The stories we all hear from our childhood about Gods is all about someone who has features similar to that of a human. In European literatures, there is no conception or existence of any other kind of God, or in other words the God which is Formless. Even if there were such examples, it was not highlighted in the eras. There were or maybe there are reasons and intentions on anthropomorphizing God, and those reasons varied over ages in society. Nonetheless, in my understanding, the image of God was never a constant, and never will be too. This very 'Humanization' results into what is known as Polytheism as everyone draws God differently and tries to relate to their concepts and believes. This also throws me in the quest of searching for the actual and only image of God, if there is any. However, a different perspective comes up when I looked into genre of Popular literature of America. In this genre, the concept of God, being Formless, is more available than the traditional God I read about with a form. This gave me the very understanding that not only time or eras are having different images of God but it is different even geographically.

This is the other God, which is formless, or 'not so human' as we say. This God is deprived of human qualities altogether and is presumably something beyond Human understanding. This God is Omnipresent yet devoid of any figure that any human can ever draw. However there has been attempts to draw this God through an art which is 'Abstract' or even by our imagination. A great example to this understanding would be the figure of Azathoth by H.P Lovecraft, where in Azathoth's description it is written, “ gnaws hungrily in inconceivable, unlighted chambers beyond time and space. (Lovecraft, Howard Philips. "Complete Works of H. P. Lovecraft (Illustrated)", 2nd ed., Delphi Classics, 2012, pp. 548.). another example of this form of Unknown sublimity would be the image of Dementors, in Harry potter's Prisoner of Azkaban (Rowling, J.K. “Harry Potter and the Prisoner of Azkaban." Bloomsbury, 8 July 1999.)

God, however, has two different images as of now in my knowledge within these two divisions (form and formless). The first one is of the most benevolent, and the other is of a 'weird' nature and characteristics. Unlike the European understanding of God, the very concepts and theories of Monotheism can be applied here as this formless God is the only power that there is, according to the followers of Monotheism. We get similar examples in William Wordsworth's romantic idea on Pantheism, where people/ romantics tend to believe or rather identifies God with the universe or regards the universe as a manifestation of God. Here the god is formless, devoid of any individual personality. There is rather no 'personal God'. Here the understanding of God is directly connected with the universe or cosmos and not something different from it. However, the 
presence of Him is not understood by many and rather it becomes an issue of curiosity that how this God really looks like.

Christianity tells us about a holy light/spirit, that represents this very formless God and which we really know less about, but we do try to figure out how it is nonetheless. During my research over American texts, I found out that American conception of Gods has this negative imagery related to it. Not very hopeful or benevolent of a being of existence. Authors like H.P Lovecraft, Stephen King has portrayed the images of God in a darker shade than what the world has presented it in before. Lovecraft's idea of the 'Azathoth' from the fiction 'The Dream-Quest of Unknown Kadath' is such a concept that can be highlighted here in this understanding of God as on him he gives a definition that is :

"Outside the ordered universe, is that blight of nethermost confusion which blasphemes and bubbles at the center of all infinity. The boundless daemon sultan Azathoth, whose name no lips dare speak aloud, and who gnaws hungrily in inconceivable, unlighted chambers beyond time and space amidst the muffled, maddening beating of vile drums and the thin monotonous whine of accursed flute" (Lovecraft, Howard Philips. "Complete Works of H. P. Lovecraft (Illustrated)", 2nd ed., Delphi Classics, 2012, pp. 548.)

Similar examples can also be seen in Stephen King's works, specially 'IT', where we can see similar definitions of a being who is beyond the comprehension of God and who, also having similar traits to that of any lovecraftian God. The Originality of this study is in providing enough evidence and hypothesis upon portraying the very image of God which is available now and at least providing enough information upon whether any image of God can be created or not..

Conventional understanding of literature and philosophies showcases the conception of God, which is too common to discuss. There is much work on 'Does God exists?' or 'God is dead'. The theory that became the very base for my dissertation is the theory provided in Rene Descartes' "Ontological Argument"about the existence of God. It postulates that God exists and it has to exist in the simplest or the most complex sense which after three centuries was discarded by Friedrich Nietzsche with his highly modern conception that 'God is Dead'. This brings me to two things :

The first being the presence of God and theories claiming it's existence that be in any form or as something formless. The second thing being the defenestration of the idea that God exists, as Nietzsche claims that God is dead now and it no more can exist.

From both the ideas, the question that I see missing is the very image of God. There is no theory concluding on the very image that God has, although there are multiple theories like the theories in Descartes' Ontological arguments, and Gottfried W. Leibniz's Theory of 'Theodicy' which tries to support Descartes' theories by providing examples upon the characteristics of God (which makes God highly humanized) and later on in the Modern Era, when Nietzsche says that "God is dead" in his book "Thus Spoke 
Zarathustra", which was only possible if God exists beforehand otherwise it can't be dead and also it has to be Humanized which we can see through Theodicy, in order to die. But there are no definite answers towards How God actually looks, or what is his actual image.

My research is based upon these theories because it is the common sense that tells me, if there was/ is God (which is based upon the theories of Descartes, Leibniz, Nietzsche), then there should also be an image of it apart from what humans have already shown us, which is absent from human understanding because concepts of humans cannot be considered for an absolution when we are dealing with something "so sublime". My research focuses upon searching the acceptability and validity of Rene Descartes' Ontological Argument, through which I am trying to find the image of God.

In order to acknowledge or establish something in our realities about anything whatsoever, it needs to exist. This existence then builds everything that we know as knowledge or information about it which concretes it's importance and existence both. This was theorised by Rene Descartes when it came to a topic like God and his characteristics. When critics, society was confused and misunderstanding the overall religion and it's teachings, when people and society were searching for something beyond them in terms of Morality, Spirituality and all other Good things, Descartes put forward his "Ontological Argument" stating that God exists and that God is a Good one as well, and there are theories (proofs) to explain it. Coming to what Descartes said in Book 5 of Ontological Argument, he writes:

"But if mere fact that I can Produce from my thought, my understanding that it belongs to his nature for he always exists, is no less clear and distinct then is the case when I prove of any shape or number that some property belongs to it's nature" . (Nolan, Lawrence, "Descartes' Ontological Argument.", The Stanford Encyclopedia of Philosophy, 2021, https://plato.stanford.edu/archives/spr2021/entries/descartesontological/.)

Instead of diverting us from reality, Descartes is trying to provide us with another method of accepting truth. In other words, if someone considers that necessary existence pertains to the idea of a perfectly supreme being, then it is true that the supremely perfect being exists. This theory supports the very existence of God and leaves me with an understanding that this God which Descartes speaks of is a perfect being from all the perspectives we know. This gives me an image that God is the most benevolent, the most knowledgeable, the most true and also the most positive being anyone can think of.

As Rene Descartes is way ahead from the age of Renaissance, it can be considered that God looks like a human being, who again is portrayed physically perfect as well. This theory was answered by a theologist Gottfried W. Leibniz with his concept of "Theodicy", which is also a term that he coined. Theodicy says or rather answers the very question that "Why in the presence of an all Good God, evil exists?", because if 
God is really "Good", why does not it protects it's men and women from the evils in the society, why it sits quiet. Theodicy throws me in a state where I intend to think that God just as a human being tries to Claim that he is all Good and actually he is not. This can be supported by John Milton's image of God who says that "there is a Hell outside us and there is a Hell within us", and from Book 1 of Paradise Lost, it can be seen that it is God who is throwing Lucifer into the eternal chaos (it is not Lucifer who is creating the eternal chaos, as it was already created by God) which later comes to be known as Hell.

With Theodicy, God's perfection can be termed as an empty perfection or rather he can be all Good but not all powerful. Maybe God is really not able to change what is happening or going to happen, be it good or bad. This is Indicating towards something, some power, which is even greater than what God is, higher than the highest of the high, who are capable of doing things which cannot be undone by even Gods. This concept is similar to what we can see in the Norse mythology, in the very story of Odin and Ragnarok. Odin being a god was aware of the future, of what destruction was going to come, of the things that was going to happen in Ragnarok, but he was unable to change the fate. Although he tried many a things in order to change the fate but the fate was unchanged, and all the destruction, evolutions happened even though Odin, the highest of the high knew about it beforehand. (Gaiman, Neil. Norse Mythology. Bloomsbury publishing, 2017.) This very conception leads me to think on the subject of fate and it's portrayal in the literature. To my understanding there is something beyond human, which is God and also something beyond God which apparently seems to be 'fate' in a lot of places. This figure, which is beyond the understanding of even those Gods whom we consider as something beyond imagination, or something we can comprehend maybe the God which I am aiming to find in this project as it can be tagged with the meaning of sublime which we basically tend to relate with Gods we know. This hypothesis seems to draw a superior image of God, something superior than every human being (Mentally and Physically). This can well found in the Bhagavad Gita, through the lines "Lord has inconceivable power. If he likes, He can reveal himself by His grace, although he is unlimited." (Swami Prabhupada, A.C Bhaktivedanta. "Bhagavad-gita as it is." 12th ed., The Bhaktivedanta book trust, April 2016, pp.566)

Here, however according to my understanding, that same God is limited to a certain extent, be that in terms of power or knowledge or any other thing as Krishna, the supreme of Godhead also meets a Human like death in his Human like form which can be heard in the hindu mythological folklore and even there are concepts of Odin's death in Norse mythological folklores. This brings me to a preliminary conclusion that the image of God that we have is a highly humanized one, who is limited at certain places as well, but well beyond our (human's) imaginations at the same time. Humanization refers to making something more civilized or to give something a human character, in simpler words it means to make something in the image of a Human being. Going back to John Milton's Paradise Lost, it has been mentioned that "men are made in the image of God", which can be interpreted into something like "God looks similar to man, it (God) is just more superior to them (humans) in everything". While speaking of something beyond 
than humans yet a human being, I can not exclude the very conception that is coming out of the modern society, mainly from F. Nietzsche. The concept of "Ubermensch" is a must in order to carry forward this quest of searching God's Image, which was a result of the very crisis in Modernity

According to Nietzsche, the Ubermensch is someone or anyone who is Beyond Man (a superman), and it can be done by tapping to any human's full potentiality in all the spheres of life. A human, yet God-like or maybe a God, yet Human-like. In order to elaborate, I would like to quote Nietzsche's descriptions upon this very Superman, which is

" There are no Higher men, we are all equal, man is but man, before God-we all are equal!

Before God! But now this God has died. And let us not be equal before this mob. You Higher man, depart from the market-place.

God has died: now we desire- that the Superman shall live”

(Nietzsche, Friedrich. "Thus Spoke Zarathustra: a Book for Everyone and No One.” translated by R.J Hollingdale., Penguin Books, 1969, pp. 297.)

Maybe an ignorable sight but the intentional usage of capital letters in "Higher" and "Superman" is done in order to give the feeling equal to that of the almighty to a common man. Men are playing Gods now. Definitely, even if a lot considered themselves this Superman, but it unfortunately remains impossible as we according to theories of Plato, are never perfect, and if we are never perfect, our creator who made us in his image is also not perfect and it can exist/ happen to be, and it can be said through the theories provided by Descartes, in his "Ontological Argument". From all of this I can say that "the form of God that I am getting here, is an imperfect one even though it looks like any other human, it has a form and it exists, as there are theories to define it's existence". And coming to Modern times, he's even more Humanized after conceptions like a God can die, just as a human being, which can be seen very evidently in Hinduism or Buddhism or even Christianity with characters like Krishna, Buddha, Sai, and Jesus Christ.

As I mentioned, all of my above research is based upon the conception of God my academia taught me which is highly influenced by European culture and Mythologies. In order to seek a difference, I expanded my readings to the literature of America and surprisingly the concept of God in American literature is actually different from what European literature shows us. Here, the God that exists mostly in literature is formless. Also, the very beings (Gods) considered here in literature is showcased on a different light altogether. This God is not the Omni-benevolent figure we generally search in the figure of God, yet someone who knows all, and is present everywhere. Rather I can say that this beyond comprehending God is more of a demonic character. I would like to support my statement with H.P Lovercraft's modern texts gave me 
Azathoth's explanation as "a monstrous nuclear chaos beyond angled space", or "ancient legend of Ultimate chaos, at whose centre sprawls the blind idiot God Azathoth, Lord of all things, encircled by his flopping horde of mindless and amorphous dancers, and lulled by the thin monotonous piping of a daemonic flute held in nameless paws". (Lovecraft, Howard Phillips. "Azathoth." Wikipedia, Wikimedia Foundation, 6 May 2021, en.wikipedia.org/wiki/Azathoth)

This elaborates upon such a creature that is not only beyond comprehensions but also about what we know less, or are at least told less about, it is rather an abstract of an image that is formed here. It is more of a destroyer who, while sitting quiet, encourages life and development and nearly all the Gods from Lovecraftian mythos are similar. It can be seen this way that God is merely a signifier, whose 'signified' is manmade and hence, literature adds new signified to the only signifier.

This, if modernised in the society where humans are playing Gods, or something beyond Human, can be seen in the works of Lovecraft's one of the closest friends, Robert Bloch and specifically in his text "Psycho". Here, the figure of Norman Bates claims certain Godly ideas as a human. While he says "I think I must have one of those faces you can't help believing” (King, Stephen. It: A Novel. Scribner, 2019, pp. 346) or "We all go a little mad sometimes" (King, Stephen. It: A Novel. Scribner, 2019, pp. 278) and it may seem like any ordinary conversation but here are implications towards the very definitive understanding of a Lovecraftian God. He is playing such a character who can't really be ignored/ doubted/ disbelieved, (which is considered as equal to this God) as humans are often subjected to all of the three mentioned. And the second idea of getting a bit mad is also something that we can connect with that of any Lovecraftian God. This idea of God was however not limited to just Modernity but also found its place in Postmodernism, through the works of Stephen King. Here, King's "It" is a text I would like to draw the attention towards, as in/ through the character of 'It', Stephen King tried to provide us with a figure of this very unknown, all powerful being through a clown/joker, named Pennywise who is always smiling. However, he also claims that the identity of this being is something that no one is aware of, the very form that it takes is due to the acceptance of it in the world of humanized Gods. 'It' is something that is beyond human conceptions like 'curse', 'Gods', 'Time', 'space', and it exists. It is something that considers itself 'eternal', as it speaks of the turtle who apparently created this universe, space and time as we know of it now and somehow, the Joker, the 'It' considers it inferior, and somehow this very creature ' It' is not restricted to anything, unlike Gods as it was hypothetically told previously. So this does makes him something superior to the Gods, humans are aware of.

Stephen King's description "I think what was here before is still here... the thing that has shown up every twenty seven years or so. Sometimes, it comes a little sooner, sometimes a little later... but It always comes... It always comes back, you see. It." (King, Stephen. It: A Novel. Scribner, 2019) . The deliberate usage of capital letters again while speaking of 'It' can be again seen which tells us that It is something equal to God, and maybe beyond it as it can't be rejected/ ignored/ changed just as fate is, to which even 
Gods are inferior.

It can be said that there lies something that still try to comprehend just as said through the concept of Cosmic Horror, but we fail to do so, and therefore the closest thing we can consider becomes God.

\section{Conclusion}

From this, I can come to an understanding that here (in American literature), God is figureless, similar to an abstract (just, it can not be drawn), and in European Literature, God is having a form, which is more like a human being. There are commonalities between these Gods Which are beyond human comprehensions in terms of abilities, and both are unpredictable by nature. But there are certain things that I would like to highlight for supporting my later concepts. From both the readings (European and American), I realize that there is a bigger figure than God, and the limitations of God. The theories put forward by Rene Descartes can help in proving the very existence of Gods, but according to his own theory, if there is something beyond human understanding, one which is equal to a sublime subject, how can it be really comprehended ? To my understanding of Sublime, it has to be something that is beyond understanding or human senses. In simpler words, it can not be described with human knowledge. If God is superior/sublime to human being according literature and it exists according to Descartes' Ontological Argument, then how to define it's form with the knowledge we have. Descartes, too, came to a conclusion that there is something beyond the figure of God, but as we can not comprehend it, hence it does not exist. Therefore, God remains the highest being known, but I beg to differ.

The very concept of Humanisation and De-humanisation is mostly misinterpreted in literature according to me. Conventional knowledge generally tends to consider something humanised if it has human features/ behaviours, which can be told giving the example of Gods with a form (Jesus, Zeus, etc), and de-humanised is that which has no form or the form itself is beyond explanations (The holy Spirit, Azathoth, etc) which to my understanding is wrong as when someone is comprehending something Sublime, that does means, the very comprehensive subject isn't very sublime. For example: "God is a Sublime subject. It can not be seen, understood completely with human senses/ knowledge", but the very moment someone is tagging something with its understanding, even it be the very basic realisation that the subject can not be understood, the subject becomes understandable. This allows me to argue that God(s), both 'form' and 'formless' are Humanized conceptions. It is the same thing that is being repeated over time and ages, with different faces which made this one concept divide into multiple concepts and every concept seemed new as well as different. This is where Infinism supports my statement, as it speaks of this Literature loop which is present. According to Infinism, every text in literature is a copy of one text that was unique, which overtime was re-mastered and re-launched to the society and it was perceived as something new and different every-time. It is different from "History repeats itself" though, as this proverb is applicable when an individual is aware of the repeating subject, whereas 
Infinism speaks of that infinite loop in literature which an individual is not aware of, hence considering every looped/ repeated subject as new. God in Forms or as something formless as the same thing, can be understood through these Infinist views.

In order to seek the real identity of God, de-humanization of it's concept is required, cause by doing so the truest form/ image of God can be discussed. It is equivalent of discussing something which is absolutely sublime. But what differs here is the conclusion of mine and what was given by Rene Descartes. He came to a conclusion that "God exists" and Ontological Argument proves it so, but my research hints towards it's impossibility. If the God (Inferior to the Sublime God, who can not be understood ever) is beyond Imagination and is Sublime, there can be no definitions that can explain him.

Descartes' theory says, in order to exist, it needs to be perfect and exist in the ideal form, but this very form according to my research is missing somehow and therefore any form/image of God can not be drawn to conclude anything. To support this, it can be said that if Gods are really uncomprehending, they are absent from the very Ideal reality of ours, and we can not think of it. As we can not think of it, it does not exist. It can be said that there are problems in the very theories provided by Rene Descartes in his Ontological Argument but then again, Human understandings can not be considered as an absolution, specially to a subject so sublime. Based upon this understanding, it can be concluded that Descartes discarded the concept of a superior God as he could not explain it, and therefore God, which we know of now, became the most superior. This is where I beg to differ because the God with an image remains Inferior to the only Sublime God, which is formless.

\section{Works Cited}

Descartes, René. "Meditations on First Philosophy:

With Selections from the Objections and Replies". 1st ed., Oxford University

Press, 2008, 1lib.in/book/891073/04d029.

Gaiman, Neil. Norse Mythology. Bloomsbury publishing, 2017.

Lovecraft, Howard Phillips. "The Complete Works of H.P Lovecraft (Illustrated)".

Delphi classics, 2014, 1lib.in/book/3676808/c585a4.

Milton, John. "Paradise Lost", editd by John Leonard., Penguin Classics, 2003.

Leibniz, Gottfried Wilhelm. "Theodicy Essays on the Goodness of God

the Freedom of Man and the Origin of Evil". CreateSpace Independent

Publishing Platform, 2016, 1lib.in/book/1260072/7ae23b.

Nietzsche, Friedrich. "Thus Spoke Zarathustra: a Book for Everyone and No One." translated by

R.J Hollingdale., Penguin Books, 1969, pp. 297.

King, Stephen. It: A Novel. Scribner, 2019.

Rowling, J.K. Harry Potter and the Prisoner of Azkaban. Bloomsbury, 1999.

Bloch, Robert. Psycho: A Novel. The Overlook Press, 2010.

Swami Prabhupada, A.C Bhaktivedanta. "Bhagavad-gita as it is." 12th ed., The 
Bhaktivedanta book trust, April 2016.

Carter, Lin. "Astro Adventures." 2nd ed., August 1987, archive.org/stream/Astro Adventures_02_1987-08_PDF/Astro-Adventures_02_1987-08_PDF_djvu.txt.

Hatfield, Gary. "René Descartes." Stanford Encyclopedia of Philosophy, Stanford University, 16 January 2014, https://plato.stanford.edu/entries/descartesontological/.

Lovecraft, Howard Phillips. “Azathoth.” The H.P. Lovecraft Wiki, lovecraft.fandom.com/wiki/Azathoth.

Lovecraft, Howard Phillips. "Azathoth.” Wikipedia, Wikimedia Foundation, 6 May 2021, en.wikipedia.org/wiki/Azathoth.

\section{The Author}

\section{Sayan Chattopadhyay}

M.A., Department of English, Adamas University

Barasat, West Bengal, India

Email: sayanchattopadhyay11@gmail.com

\section{The Article}

Date sent: 09/06/2021

Date revised: 11/07/2021

Date Accepted: 14/07/2021 